\title{
CERTAINTY-UNCERTAINTY AND “ADDITIONAL” INFORMATION
} AS FACTORS CONTRIBUTING TO A CHANGE IN DECISION
IN THREE GROUPS OF PARTICIPANTS - BETTING SHOPS,
TUDENTS OF HUMANITIES AND ECONOMICS/ENGINEERING

\author{
Ivan Sarmány-Schuller', Adriana Kiššováll \\ I - Slovak Academy of Sciences, Bratislava, Slovakia \\ II - Constantine the Philosopher University, Nitra, Slovakia
}

\section{ABSTRACT}

The aim of the research was to find out the preferred decision in an economic game. Our sample comprised 433 participants (students of humanities and economics/ engineering and customers of betting shops) who were administered this game twice. The wording for the second choice was changed according to two theorems based on this game (Samuelson and Rabin theorems). Our aim was to find out if there were differences in the choice of game between the groups of participants, and if uncertainty and change of wording was related to change in decision. Results show that the most preferred possibility in all three groups of participants was to not play any game. Participants did not make any changes to their decisions even in repeated choice when the wording was changed; they still adhered to their previous choice. Self-assessment of certainty and uncertainty proved significant only in the case of students of humanities (psychology and social work) where assessing the decision as uncertain led to its change. On the contrary, if a decision was assessed as certain, it was not subject to any change later. Students of humanities had significantly higher score of pathological certainty (C3) than other degrees of the Uncertainty-Certainty Scale, which is related to a higher willingness to play the offered games. JEL CLASSIFICATION \& KEYWORDS

D81 DECISION MAKING - SAMUELSON THEOREM - LOSS AVERSION - RISK AVERSION - RABIN THEOREM - CERTAINTY AND UNCERTAINTY — SCIENCE ॥ UNIVERSITY - QUALITY

\section{INTRODUCTION}

Decision making is a multidisciplinary field of study and can be approached from three perspectives - in a normative, descriptive and prescriptive approach (Bačová, 2010).

The normative approach is the longest in existence and is based on the classic economic theory (Baláž, 2009), which is in many aspects followed by the expected utility theory (von Neumann, Morgenstern, 1944).

The basic idea of the expected utility theory is that people base their decisions on two principles. They are the extent of utility, brought by a certain decision, and the probability of occurrence of this possibility (Baláž, 2009, Baláž, 2010).

The expected utility theory brought a significant progress in explaining risk aversion (avoiding risks) and tolerance (accepting risks). Two reasons were stated, why people may exhibit both forms of behavior. Firstly, it was because there is a certain joy from participating in games or other forms of risk activities, which is included in utility function, and second because the utility function itself says that people are risk averse when larger sums of money are involved while showing risk tolerance with smaller sums (Baláž, 2009).

\section{' expssarm@savba.sk}

"adrianakissova@gmail.com
Expected utility theory was succeeded by prospect theory (Kahneman \& Tversky, 1979), which was later revised to cumulative prospect theory (Tversky \& Kahneman, 1992). Prospect theory is in agreement with the expected utility theory in regard to the people's efforts to maximize utility, but the classical perception of rationality is replaced by conditioned rationality that allows the influence of the amount and character of available information (Baláž, 2009; Baláž, 2010; Kahneman \& Tversky, 1979).

The expected utility theory can be perceived as a specific form of the prospect theory, where people behave completely rationally (Baláž, 2009). One of the main differences is that within the expected utility theory, values of gains and losses are perceived linearly, while within the prospect theory, the value is concave with gains but convex with losses (Baláž, 2009; Kahnemann \& Tversky, 1979; Tversky \& Kahneman, 1992). Loss aversion was defined in course of describing the value function. It is considered as an emotional deviation from rationality that causes losses of the same value as gains to be perceived stronger meaning that the disappointment from losing $\$ 100$ would be greater than the satisfaction from gaining the same sum (Tversky \& Kahneman, 1992; Kahneman, Knetsch \& Thaler, 1990).

The problem presented by W. Samuelson (1963) to his colleague can reflect both different views of the expected utility theory, as well as prospect theory.

The original problem was a simple game of coin toss, where players could lose $\$ 100$ or gain $\$ 200$, depending on the side of coin that fell. The colleague rejected this game, however, he said that if there was a possibility to repeat the coin toss 100 times, he would have accepted it

This behavior did not correspond with what expected utility theory anticipated in such situation. W. Samuelson (1963) said that finding the possibility of loss to be very small in the case of repeated coin toss is caused by fallacy of large numbers. His theorem says that if the expected utility of an investment is worse than its absence, then no sequence of such independent investments can have favorable expected utility. In case of our bet it means that if you refuse to participate in a game with single toss, then you should refuse any sequence of such tosses. He said that his colleague should have rather asked for a sequence of 100 games, where each was $100^{\text {th }}$ as big, as that would subdivide the risk instead of increasing it (in this case it would be $\$ 1$ against \$2)

Another look at this scenario was Rabin's (2000). He criticized the expected utility theory, which according to him, makes wrong predictions about the relationship between risk aversion over modest stakes and risk aversion over large stakes, and he used this bet and following response of his colleague as an example. According to Rabin, not changing the approach to these risky situations (as expected in Samuelson's theorem) does not correspond to the real situation, because "virtually everybody" (Rabin, 2000, 
p. 1288) would have seen the hundred times repeated bet as profitable, as the aggregated gamble has the expected gain of $\$ 5,000$ and there is only negligible risk. The chance that any loss would have occurred is $1 / 700$ and the possibility of losing more than $\$ 1,000$ is $1 / 25000$

Research (Benartzi \& Thaler, 1999; Keren, 1991) indicated that participants more frequently chose a multiple opportunity to play, either after they were shown a graphical layout of loss chances or when they had to select a preferred number of repetitions from the offered options.

The combination of games corresponding to the Samuelson theorem has been explained by myopic loss aversion, which means that decisions and the results are too narrow. In the case of the stake example this means that a person, who would assess it myopically and decide that one coin toss is disadvantageous for him/her, would also reject a series of such stakes (Benartzi \& Thaler, 1999).

Subjective probability for accepting a single throw is also biased. It is the law of small numbers, a phenomenon related to representativeness, in which participants attach greate importance to small numbers than what they actually possess (Benartzi \& Thaler, 1999; Kahneman \& Tversky, 1979).

Decision making in similar tasks, but also in real life is related to uncertainty that can be categorized by means of objective and subjective probability. Uncertainty, where probability can be objectively determined, is also known as risk, and subjective probabilities are simply called uncertainty or ambiguity. People form this probability from available information, but contrary to objective probability, this kind will differ in individual people according to their own assessment of the obtained information (Baláž, 2009).

Thus, uncertainty results from information available from various sources on the given problem to a person. Information is facts, previously not known, and they reducing uncertainty related to a given problem. They can be useful, but also useless, true or false, and therefore, it is unwise to mistake the amount of information for its value. Information forms a counterweight to uncertainty because the more relevant information we possess, the more we reduce uncertainty (Garner, 1962).

Cognitive uncertainty is a term that represents uncertainty from the aspect of processing available information and validity of this processing. As opposed to information uncertainty that is related to concrete information and to their correctness (incorrectness) and sufficiency, a person can perceive cognitive uncertainty even if the information available is seen as sufficient. Its essence is that one does not need to be convinced of the correctness of his/her judgment, because they may fear they made a mistake when choosing and evaluating possible results (Clausing, 2000)

Therefore, it can be concluded that experiencing certainty and uncertainty in the subjective (or internal) perception is based not only on the information available, but also on the human personality, and it depends on the complexity of cognitive situations (Garner, 1962; Kováč, 1969 in SarmánySchuller, 1999).

\section{Methods and Aims}

The research sample comprises 433 participants. 218 were students of humanities (UKF in Nitra), 172 were students of economics/engineering (STI in Dubnica nad Váhom) and 43 were customers of betting shops.
Data was obtained by means of a three-part questionnaire. The first part was a bet (Samuelson, 1963), adapted to a decimal value (Benartsi \& Thaler, 1999) in our currency (Euro).

- Imagine that you are offered a game that will begin with a zero account. This game would be coin toss, where one side would mean gain and the other side loss. The sides would be determined before the game starts. If the winning side falls, you gain 10 Euro. If the other side, the losing side, falls, you lose 5 Euro.

Will you participate in the game? Yes/No

- Another game would also be coin toss. Similarly to the previous one, the winning side means gaining 10 Euro and the losing side means losing 5 Euro. This game would be repeated 100 times.

Will you participate in this game? Yes/No

Then the participants rated certainty/uncertainty in their decisions on a 4-point scale (completely certain - certain uncertain - completely uncertain).

The third part of the questionnaire was the Uncertainty-Certainty Scale (Kováč, 1969 in SarmánySchuller, 1999) that consisted of 54 statements, where participants made forced choices between two alternative situation assessments. If these two alternatives do not suit them, they can write the choice c, as the third possibility. However, this serves only as a last resort, and the participants are informed of this beforehand. This choice is not valid for the evaluation of this instrument.

In the last part the participants were randomly offered three different modified versions of the multiple bet, which were extended either by an indication of the maximum possible gain, loss, or probability of loss, and these were given in verbal form.

Our main aim was to find which theorem is a more real representation of the research sample. Due to counter indications of both theorems, the following question was put for the first part:

VO1a: What is the preference of individual combinations of games in the group of students of humanities?

VO1b: What is the preference of individual combinations of games in the group of students of economics/engineering?

V01c: What is the preference of individual combinations of games in the group of customers of betting shops?

Next, our aim was to find if a change occurs in the decision when the choice is repeated. Uncertainty/Certainty resulting from information should remain on the same level as information in the third part (highest gain and loss) did not possess any added value, thus:

$\mathrm{H} 1 \mathrm{a}$ : We assume that the task containing the highest possible gain will not affect the change of preferences in the group of students of humanities.

$\mathrm{H} 1 \mathrm{~b}$ : We assume that the task containing the highest possible gain will not affect the change of preferences in the group of students of economics/engineering.

$\mathrm{H} 1 \mathrm{c}$ : We assume that the task containing the highest possible gain will not affect the change of preferences in the group of customers of betting shops.

H2a: We assume that the task containing the highest possible loss will not affect the change of preferences in the group of students of humanities. 
$\mathrm{H} 2 \mathrm{~b}$ : We assume that the task containing the highest possible loss will not affect the change of preferences in the group of students of economics/engineering.

H2c: We assume that the task containing the highest possible loss will not affect the change of preferences in the group of customers of betting shops.

Probability data is, similarly to the previous two, a piece of information without any value as it does not contain any new findings that could not be derived without it (Garner 1962). Nevertheless, it has been shown that the graphical indication of probability affected the subsequent change in decision (Benartzi \& Thaler, 1999), thus we chose the question:

VO2a: Will there be a change in preference in the group of students of humanities within a repeated choice, when the probability of loss is given?

VO2b: Will there be a change in preference in the group of students of economics/engineering within a repeated choice, when the probability of loss is given?

VO2c: Will there be a change in preference in the group of customers of betting shops within a repeated choice, when the probability of loss is given?

The following hypotheses were set for the subjective (cognitive) uncertainty:

H3a: We assume that in case of a certain decision there will not be a change of game preference in the case of a repeated decision making in the group of students of humanities.

$\mathrm{H} 3 \mathrm{~b}$ : We assume that in case of a certain decision there will not be a change of game preference in the case of a repeated decision making in the group of students of economics/engineering.

$\mathrm{H} 3 \mathrm{c}$ : We assume that in case of a certain decision there will not be a change of game preference in the case of a repeated decision making in the group of customers of betting shops.

$\mathrm{H} 4 \mathrm{a}$ : We assume that in the case of an uncertain decision there will be a change of game preference in the case of repeated decision making in the group of students of humanities.

$\mathrm{H} 4 \mathrm{~b}$ : We assume that in the case of an uncertain decision there will be a change of game preference in the case of repeated decision making in the group of students of economics/engineering.

$\mathrm{H} 4 \mathrm{c}$ : We assume that in the case of an uncertain decision there will be a change of game preference in the case of repeated decision making in the group of customers of betting shops.

In case of the Uncertainty-Certainty Scale (Kováč, 1969 in Sarmány-Schuller, 1999), according to which certainty and uncertainty constitute two extremities of its experience, we put the following research questions:

VO3a: Is there a significant difference between the degrees of uncertainty-certainty and the game preference in the first choice in students of humanities?

VO3b: Is there a significant difference between the degrees of uncertainty-certainty and the game preference in the first choice in students of economics/engineering?

VO3c: Is there a significant difference between the degrees of uncertainty-certainty and the game preference in the first choice in customers of betting shops?

\section{Results}

Table 1: Preference of game combinations in the first choice $(n=433)$

\begin{tabular}{|c|c|c|c|c|c|c|c|c|c|c|c|c|}
\hline & \multicolumn{4}{|c|}{$\begin{array}{l}\text { Humanities } \\
\left(\mathrm{n}_{1}=218\right)\end{array}$} & \multicolumn{4}{|c|}{$\begin{array}{c}\text { Economics/Engineering } \\
\left(n_{2}=172\right)\end{array}$} & \multicolumn{4}{|c|}{$\begin{array}{c}\text { Betting Shops } \\
\left(n_{3}=43\right)\end{array}$} \\
\hline & $Y / Y$ & Y/N & $\mathrm{N} / \mathrm{Y}$ & $\mathrm{N} / \mathrm{N}$ & $\mathrm{Y} / \mathrm{Y}$ & $\mathrm{Y} / \mathrm{N}$ & $\mathrm{N} / \mathrm{Y}$ & $\mathrm{N} / \mathrm{N}$ & $\mathrm{Y} / \mathrm{Y}$ & $\mathrm{Y} / \mathrm{N}$ & $\mathrm{N} / \mathrm{Y}$ & $\mathrm{N} / \mathrm{N}$ \\
\hline $\mathrm{n}$ & 54 & 33 & 23 & 108 & 29 & 38 & 15 & 90 & 7 & 4 & 2 & 30 \\
\hline$\%$ & 24.8 & 15.1 & 10.6 & 49.5 & 16.9 & 22.1 & 8.7 & 52.3 & 16.3 & 9.3 & 4.7 & 69.8 \\
\hline ne & 54.5 & 54.5 & 54.5 & 54.5 & 43 & 43 & 43 & 43 & 10.8 & 10.8 & 10.8 & 10.8 \\
\hline$x^{2}$ & \multicolumn{4}{|c|}{79.211} & \multicolumn{4}{|c|}{74.744} & \multicolumn{4}{|c|}{47.14} \\
\hline p & \multicolumn{4}{|c|}{0} & \multicolumn{4}{|c|}{0} & \multicolumn{4}{|c|}{0} \\
\hline R & -0.5 & -21.5 & -31.5 & 53.5 & -14 & -5 & -28 & 47 & -3.8 & -6.8 & -8.8 & 19.2 \\
\hline SR & -0.068 & -2.91 & -4.27 & 7.25 & -2.13 & -0.762 & \begin{tabular}{|l|} 
\\
\end{tabular} & 7.17 & -1.16 & -2.07 & -2.68 & 5.84 \\
\hline p & 0.946 & 0.0036 & 0.0001 & 0.0001 & 0.0332 & 0.4461 & 0.0001 & 0.0001 & $|0.246|$ & 0.0385 & 0.0074 & 0.0001 \\
\hline \multicolumn{13}{|c|}{$\begin{array}{l}\text { Legend: } \mathrm{Y} / \mathrm{Y} \text { - choice of both games, } \mathrm{Y} / \mathrm{N}-\text { choice of one-toss } \\
\text { game, } \mathrm{N} / \mathrm{Y} \text { - choice of game with } 100 \text { repetitions, } \mathrm{N} / \mathrm{N}-\text { no game, } \\
\mathrm{R} \text { - residuals, } \mathrm{SR} \text { - standard residuals }\end{array}$} \\
\hline & & & & & & & & & & & & \\
\hline
\end{tabular}

Game preference in the first choice was validated by chi-square. Standard residuals showed that participants in all groups most frequently chose to not play any game $(\mathrm{p} 1<.0001 ; \mathrm{p} 2<.0001 ; \mathrm{p} 3<.0001)$. On the contrary, the least frequent choice of all three groups was to only play the game with 100 repetitions $(\mathrm{p} 1<.0001$; $\mathrm{p} 2<.0001$; p3 $=.0074)$, and in the case ofstudents of humanities also the game with one coin toss only $(\mathrm{p} 1=.0036)$.

Table 2: Chi-square test of good agreement for change (yes/no) and three versions of the second choice of games

\begin{tabular}{|c|c|c|c|c|c|c|c|}
\hline & & & \multicolumn{2}{|c|}{ Change } & \multirow[b]{2}{*}{$x^{2}$} & \multirow[b]{2}{*}{ df } & \multirow[b]{2}{*}{$p$} \\
\hline & & & yes & no & & & \\
\hline \multirow{12}{*}{ Humanities } & \multirow{4}{*}{ HV } & $\mathrm{n}$ & 15 & 82 & \multirow{12}{*}{0.481} & \multirow{12}{*}{2} & \multirow{12}{*}{0.786} \\
\hline & & ne & 16.9 & 80.1 & & & \\
\hline & & SR & -0.5 & 0.2 & & & \\
\hline & & $A R$ & -0.7 & 0.7 & & & \\
\hline & \multirow{4}{*}{ HP } & ne & 11 & 48 & & & \\
\hline & & ne & 10.3 & 48.7 & & & \\
\hline & & SR & 0.2 & -0.1 & & & \\
\hline & & AR & 0.3 & -0.3 & & & \\
\hline & \multirow{4}{*}{ PP } & $\mathrm{n}$ & 12 & 50 & & & \\
\hline & & ne & 10.8 & 51.2 & & & \\
\hline & & SR & 0.4 & -0.2 & & & \\
\hline & & AR & 0.5 & -0.5 & & & \\
\hline \multirow{12}{*}{$\begin{array}{l}\text { Economics/ } \\
\text { Engineering }\end{array}$} & \multirow{4}{*}{ HV } & $\mathrm{n}$ & 5 & 51 & \multirow{12}{*}{2.6006} & \multirow{12}{*}{2} & \multirow{12}{*}{0.272} \\
\hline & & ne & 7.5 & 48.5 & & & \\
\hline & & SR & -0.9 & 0.4 & & & \\
\hline & & AR & -1.2 & 1.2 & & & \\
\hline & & $\mathrm{n}$ & 7 & 51 & & & \\
\hline & HP & ne & 7.8 & 50.2 & & & \\
\hline & $\mathrm{HP}$ & SR & -0.3 & 0.1 & & & \\
\hline & & $\mathrm{AR}$ & -0.4 & 0.4 & & & \\
\hline & \multirow{4}{*}{ PP } & $\mathrm{n}$ & 11 & 47 & & & \\
\hline & & ne & 7.8 & 50.2 & & & \\
\hline & & SR & 1.2 & -0.5 & & & \\
\hline & & AR & 1.5 & -1.5 & & & \\
\hline \multirow{12}{*}{ Betting Shops } & \multirow{4}{*}{ HV } & $\mathrm{n}$ & 0 & 15 & \multirow{12}{*}{4.568} & \multirow{12}{*}{2} & \multirow{12}{*}{0.101} \\
\hline & & ne & 1.4 & 13.6 & & & \\
\hline & & SR & -1.2 & 0.4 & & & \\
\hline & & AR & -1.5 & 1.5 & & & \\
\hline & \multirow{4}{*}{ HP } & $\mathrm{n}$ & 1 & 14 & & & \\
\hline & & ne & 1.4 & 13.6 & & & \\
\hline & & $\mathrm{SR}$ & -0.3 & 0.1 & & & \\
\hline & & $\mathrm{AR}$ & -0.4 & 0.4 & & & \\
\hline & \multirow{4}{*}{ PP } & $\mathrm{n}$ & 3 & 10 & & & \\
\hline & & ne & 1.2 & 11.8 & & & \\
\hline & & SR & 1.6 & -0.5 & & & \\
\hline & & AR & 2 & -2 & & & \\
\hline
\end{tabular}

Legend: HV - gain value, HP - loss value, PP - loss probability, $\mathrm{SR}$ - standard residuals, AR - adjusted residuals

Source: Authors 
When calculating the preference of games depending on the task, no changes in any of the groups $(\mathrm{p} 1=.786$, p2 $=.272, \mathrm{p} 3=.101$ ) in any of the three options occurred. Both hypotheses ( $\mathrm{H} 1 \mathrm{a}, \mathrm{b}, \mathrm{c}$ and $\mathrm{H} 2 \mathrm{a}, \mathrm{b}, \mathrm{c})$ were confirmed. Also, in the case of indicated loss probability $(\mathrm{VO} 2 \mathrm{a}, \mathrm{b}, \mathrm{c})$ the change in game preference was not statistically significant.

\begin{tabular}{|c|c|c|c|c|c|c|c|}
\hline & & & & ange & & & \\
\hline & & & yes & no & $x^{2}$ & $\mathrm{df}$ & $p$ \\
\hline \multirow{8}{*}{ Humanities } & \multirow{4}{*}{$\begin{array}{l}\text { Completely certain } \\
+ \text { Certain }\end{array}$} & $\mathrm{n}$ & 25 & 160 & \multirow{8}{*}{13.033} & \multirow{8}{*}{1} & \multirow{8}{*}{0} \\
\hline & & ne & 32.2 & 152.8 & & & \\
\hline & & $\mathrm{SR}$ & \begin{tabular}{|l|}
-1.3 \\
\end{tabular} & \begin{tabular}{|l|}
0.6 \\
\end{tabular} & & & \\
\hline & & $\mathrm{AR}$ & \begin{tabular}{|l|} 
\\
\end{tabular} & 3.6 & & & \\
\hline & \multirow{4}{*}{$\begin{array}{l}\text { Completely uncertain } \\
+ \text { Uncertain }\end{array}$} & $\mathrm{n}$ & 13 & 20 & & & \\
\hline & & ne & 5.8 & 27.2 & & & \\
\hline & & SR & 3 & -1.4 & & & \\
\hline & & $\mathrm{AR}$ & 3.6 & -3.6 & & & \\
\hline \multirow{8}{*}{$\begin{array}{l}\text { Economics/ } \\
\text { Engineering }\end{array}$} & \multirow{4}{*}{$\begin{array}{l}\text { Completely certain } \\
+ \text { Certain }\end{array}$} & $\mathrm{n}$ & 18 & 125 & \multirow{8}{*}{0.451} & \multirow{8}{*}{1} & \multirow{8}{*}{0.502} \\
\hline & & ne & 19.1 & 123.9 & & & \\
\hline & & SR & \begin{tabular}{|l|} 
\\
\end{tabular} & \begin{tabular}{|l|}
0.1 \\
\end{tabular} & & & \\
\hline & & AR & $-0.7 \mid$ & 0.7 & & & \\
\hline & \multirow{4}{*}{$\begin{array}{l}\text { Completely uncertain } \\
+ \text { Uncertain }\end{array}$} & $\mathrm{n}$ & 5 & 24 & & & \\
\hline & & ne & 3.9 & 25.1 & & & \\
\hline & & SR & 0.6 & -0.2 & & & \\
\hline & & $\mathrm{AR}$ & 0.7 & -0.7 & & & \\
\hline \multirow{8}{*}{$\begin{array}{l}\text { Betting } \\
\text { shops }\end{array}$} & \multirow{4}{*}{$\begin{array}{l}\text { Completely certain } \\
+ \text { Certain }\end{array}$} & $\mathrm{n}$ & 3 & 31 & \multirow{8}{*}{0.044} & \multirow{8}{*}{1} & \multirow{8}{*}{0.843} \\
\hline & & $\mathrm{ne}$ & \begin{tabular}{|l|}
3.2 \\
\end{tabular} & \begin{tabular}{|l|}
30.8 \\
\end{tabular} & & & \\
\hline & & SR & \begin{tabular}{|l|}
0 \\
\end{tabular} & 0 & & & \\
\hline & & $\mathrm{AR}$ & \begin{tabular}{|l|} 
\\
\end{tabular} & 0.2 & & & \\
\hline & \multirow{4}{*}{$\begin{array}{l}\text { Completely uncertain } \\
\text { + Uncertain }\end{array}$} & $\mathrm{n}$ & 1 & 8 & & & \\
\hline & & $n e$ & \begin{tabular}{|l|}
0.8 \\
\end{tabular} & 8.2 & & & \\
\hline & & SR & 0.2 & 0 & & & \\
\hline & & $\mathrm{AR}$ & \begin{tabular}{|l|}
0.2 \\
\end{tabular} & -0.2 & & & \\
\hline
\end{tabular}

Certainty-uncertainty self-assessment is statistically significant in the change between the first and repeated choice $\left(X^{2}=13.033, p<.0001\right)$ in the group of students of humanities - people who assessed their decision as certain made changes less frequently $(p=.000)$ and people who assessed their decision as uncertain decided to make a change more often than in the other cases $(p=.000)$. No statistically significant differences were found in other groups. Table 4: Kruskall-Wallis one-way analysis of variance for certainty-
uncertainty levels in the preference of possible game combinations in the first choice

\begin{tabular}{|c|c|c|c|c|c|c|}
\hline \multicolumn{2}{|c|}{} & $\mathrm{N} 1$ & $\mathrm{~N} 2$ & $\mathrm{~N} 3$ & $\mathrm{I}$ & $\mathrm{I}$ \\
\hline \multirow{3}{*}{ Humanities } & $\mathrm{X}^{2}$ & 3.546 & 0.977 & 1.77 & 4.647 & 14.581 \\
\cline { 2 - 7 } & $\mathrm{df}$ & 3 & 3 & 3 & 3 & 3 \\
\cline { 2 - 7 } & $\mathrm{p}$ & 0.315 & 0.807 & 0.621 & 0.2 & 0.002 \\
\hline \multirow{3}{*}{$\begin{array}{c}\text { Economics/Enginee } \\
\text { ring }\end{array}$} & $\mathrm{X}^{2}$ & 2.235 & 0.911 & 1.993 & 1.395 & 0.453 \\
\cline { 2 - 7 } & $\mathrm{df}$ & 3 & 3 & 3 & 3 & 3 \\
\cline { 2 - 7 } Betting Shops & $\mathrm{p}$ & 0.525 & 0.823 & 0.574 & 0.707 & 0.929 \\
\hline \multirow{3}{*}{} & $\mathrm{x}^{2}$ & 0.599 & 0.78 & 1.436 & 1.297 & 7.339 \\
\cline { 2 - 7 } & $\mathrm{df}$ & 3 & 3 & 3 & 3 & 3 \\
\cline { 2 - 7 } & $\mathrm{p}$ & 0.897 & 0.854 & 0.697 & 0.73 & 0.062 \\
\hline \hline
\end{tabular}

Legend: N1 - normal uncertainty, N2 - increased uncertainty, N3 pathological uncertainty, I1 - normal certainty, I3 - pathological certainty

Source: Authors
The scale of pathological certainty proved as statistically significant in the choice of game combinations in students of humanities $(p=.002)$. In students of economics/engineering no degree of certainty-uncertainty was statistically significant and in the customers of betting shops no statistical significance was found, but pathological certainty (I3) was sufficiently near $(p=.065)$ to be subjected to further analysis together with pathological certainty in students of humanities.

Table 5: Man-Whitney $U$ test for the 13 level in the preference of possible game combinations in the first choice

\begin{tabular}{|c|c|c|c|c|c|c|c|}
\hline & & $\mathrm{Y} / \mathrm{Y}-\mathrm{Y} / \mathrm{N}$ & $\mathrm{Y} / \mathrm{Y}-\mathrm{N} / \mathrm{Y}$ & $\mathrm{Y} / \mathrm{Y}-\mathrm{N} / \mathrm{N}$ & $\mathrm{Y} / \mathrm{N}-\mathrm{N} / \mathrm{Y}$ & $\mathrm{Y} / \mathrm{N}-\mathrm{N} / \mathrm{N}$ & $\mathrm{N} / \mathrm{Y}-\mathrm{N} / \mathrm{N}$ \\
\hline Human & $\mathrm{U}(\mathrm{M}-\mathrm{W})$ & 432 & 585.5 & 2020 & 193.5 & 1180 & 913 \\
\hline numant & $p$ & 0.002 & 0.99 & 0.013 & 0.008 & 0.064 & 0.064 \\
\hline Betting & $U(M-W)$ & 7.5 & 7 & 43.5 & 1.5 & 41 & 7.5 \\
\hline Shops & $p$ & 0.194 & 1 & 0.026 & 0.233 & 0.431 & 0.085 \\
\hline $\begin{array}{l}\text { Legend } \\
\text { game, } \wedge\end{array}$ & $\begin{array}{l}\mathrm{d}: Y / Y- \\
N / Y-c h\end{array}$ & choice & f both & games, Y & $\mathrm{r} / \mathrm{N}-\mathrm{ch}$ & $\begin{array}{l}\text { oice of o } \\
\mathrm{N} / \mathrm{N}-\text { no }\end{array}$ & $\begin{array}{l}\text { ne-toss } \\
\text { game }\end{array}$ \\
\hline Source & Authors & & & & & & \\
\hline
\end{tabular}

Statistical significance was shown in pathological uncertainty in students of humanities in the choice of both games $(Y / Y)$ that occurred more frequently than the choice of one coin toss game, $\mathrm{Y} / \mathrm{N}(\mathrm{p}=.002)$, or no game, $\mathrm{N} / \mathrm{N}$ $(p=.026)$. Choice of 100 repetitions of the game $(N / Y)$ occurred significantly more frequently than the choice of one coin toss game, $\mathrm{Y} / \mathrm{N}(\mathrm{p}=.008)$. Customers of betting shops significantly more frequently $(p=.026)$ chose both games $(\mathrm{Y} / \mathrm{Y})$ then no game $(\mathrm{N} / \mathrm{N})$.

\section{Discussion}

Our result, showing that in all three groups participants preferred the possibility to not play any game, did not correspond with the theory of M. Rabin (2000) based on the prospect theory that people perceiving the highly advantageous probabilities of the repeated game will prefer this game only, in other words a combination where they will reject the one coin toss game. On the contrary, this game was the least preferred and only 21 participants decided to play this game.

This means that most of our research participants demonstrated loss aversion, or showed myopic loss aversion (Benartzi \& Thaler, 1999). This conclusion is more in agreement with the older one of the two theorems (Samuelson, 1963) based on the expected utility theory. Nevertheless, we cannot consider the conclusion about human behavior based on both theorems as correct or incorrect. However, we can conclude that they are not so much generalizable, it could be argued that all people behave this way and not otherwise. Both are rather inclined to one of the several possible behaviors and describe the view of the problem from the given aspect.

That not all variants are advantageous and, nevertheless, we chose them, is the result of the decision making process being affected by many heuristics, biases and fallacies (Baláž, 2009; Benartzi \& Thaler, 1999). In case of the repeated choice, we gave participants additional information that could lead to their change in decision. Participants adhering to their original decisions (Table 2) can be credited to the changed formulations bringing no new information, and thus they had no reason to make a change. These were information on the possible loss value, gain value and loss probability - all of them easily deduced from the original task. Focusing on possible gain or loss is the easiest and most common way of evaluating a situation (in this case a bet), although it cannot be said that it is a precise assessment (Baláž, 2009). And probability is one of the 
foundation stones of the expected utility theory and prospect theory (Kahneman, Tversky, 1979; von Neumann, Morgenstern, 1944). According to M. Rabin (2000), exactly this probability awareness in the 100 repetitions Samuelson stake should suffice to make people decide to play this game. We can conclude that participants became aware of these elements in the first choice and in their second choice this information was just a repetition of known facts that did not have any persuasive effect in verbal form, even though the graphic portrayal of probability (even worse that virtually offered by the repeated game) had an effect on participants' reconsidering their choice (Benartzi \& Thaler, 1999).

\section{CONCLUSION}

Among the degrees of uncertainty-certainty (Kováč, 1969 in Sarmány-Schuller, 1999), a significant one is the so called pathological certainty (I3) that, as given by its name, represents increased certainty. In our case, this was shown in the group of students of humanities, who often associated this degree of certainty with the possibilities of playing games and play them more frequently then play little or not at all (Table 5). We can thus conclude that pathological certainty contributes to the willingness to take risks.

The results obtained from the group of customers of betting shops agree with this conclusion, however, a significant difference was shown only in case of accepting both games as opposed to accepting no game at all. Nevertheless, students of economics/engineering did not show any significant differences on any degree of certaintyuncertainty, which is in disagreement with our conclusion.

Subjective assessment of uncertainty, in which participants had to express certainty and uncertainty felt with their decision also brought significant results only in the group of students of humanities, who showed that those participants who assessed their decisions as uncertain tended to subsequently change them, and conversely those who assessed their decision as certain, followed it also in their next choice.

Although we successfully answered several questions, many new ones emerged, especially related to certaintyuncertainty. It would be interesting to take a closer look at why students of economics/engineering, unlike students of humanities, did not show statistical significance in the aforementioned cases, as well as focus on the pathological certainty, which can be related to greater willingness to take risks and thus, participate in financial (and real) games and stakes.

\section{REFERENCES}

Bačová, V. (2010). Psychológia usudzovania a rozhodovania. In Bačová, V. (ed.). Rozhodovanie a usudzovanie: Pohl'ad psychológie a ekonómie I. Bratislava: Ústav experimentálnej psychológie SAV, pp. 14-47.

Baláž, V. (2010). Prospektováa teoria a jej miesto v ekonomickom mysleni. In Bačová, V. (ed.). Rozhodovanie a usudzovanie: Pohl'ad psychológie a ekonómie I. Bratislava: Ústav experimentáalnej psychológie SAV, pp. 88-132.

Benartzi, S., \& Thaler, R. H. (1999). Risk Aversion or Myopia? Choices in Repeated Gambles and Retirement Investments. In Management Science, Vol. 45, no. 3, pp. 364-381.

Clausing, T. (2000). Cognitive Uncertainty in Games: A Note on Limited Information Processing and Backward Induction. In Game Theory and Information, 0004001, EconWPA.

Garner, W. R. (1962). Uncertainty and Structure as Psychological Concepts. New York: John Wiley \& Sons, pp. 369.

Kahneman, D. Knetch, J. L., \& Thaler, R. H. (1990). Experimental Tests of the Endowment Effect and the Coase Theorem. In The Journal of Political Economy, Vol. 98, no. 6, pp. 1325-1348.
Kahneman, D., \& Tversky, A. (1979). Prospect Theory: An Analysis of Decision under Risk. In Econometrica, Vol. 47, no. 2, pp. 263-292. Keren, G. (1991). Additional Tests of Utility Theory under Unique and Repeated Conditions. In Journal of Behavioral Decision Making, Vol. 4, no. 4., pp. 297-304.

Rabin, M. (2000). Risk aversion and expected utility theory: A calibration theorem. In Econometrica, vol. 68, no. 5, pp. 1281-1292.

Samuelson, P. (1963). Risk and Uncertainty: A Fallacy of Large Numbers. In Samuelson, P. (1966). In The Collected scientific papers of Paul A. Samuelson. Cambridge: The Massachusetts Institute of Technology, pp. 153-158.

Sarmány-Schuller, I. (1999). Neistota-istota: Prípad kauzálnej neistoty. In Bratská, M., Naništová, E., Sarmány-Schuller, I. (eds.). Reflexie súčasnej psychológie na Slovensku. Zborník IX. Zjazdu slovenských psychológov, Bratislava: STIMUL, pp. 13-19.

Tversky, A., \& Kahneman, D. (1992). Advances in Prospect Theory: Cumulative Representation of Uncertainty. $n$ Journal of Risk and Uncertainty, Vol. 5, no. 4, pp. 297-323.

Von Neumann, J., \& Morgenstern, O. (1944). Theory of Games and Economic Behaviour. Princeton: Princeton University Press, pp. 625. 